\title{
COVID-19 with a Fatal Outcome in a Kidney Transplant Recipient: Case Report
}

\author{
Renal Transplant Hastasında Fatal COVID-19: Olgu Sunumu
}

\author{
(D) Bekir Voyvoda \\ University of Health Sciences Turkiye, Kocaeli Derince Training and Research Hospital, Organ Transplantation Center, Kocaeli, Turkiye
}

\begin{abstract}
Coronavirus disease 2019 (COVID-19) has become a pandemic, with a mortality of up to 10\% in the general population. Comorbidities such as diabetes and hypertension are common among the elderly. The clinical manifestations of viral pneumonia associated with COVID19 vary widely, from mild to severe, in patients who underwent solid organ transplantation, an immunosuppressed patient group. Further large-scale studies regarding the screening and treatment approaches for COVID-19 among patients undergoing transplantation are required. Herein, we report the case of a patient who underwent renal transplantation and developed the COVID-19 infection that resulted in mortality.
\end{abstract}

Keywords: SARS-CoV-2 infection, COVID-19, Immunosuppression, Kidney transplantation, Treatment

Öz

Koronavirüs hastalığı (COVID-19) günümüzde pandemik enfeksiyon olarak görülmekte ve genel popülasyonda mortalite oranı \%3'lere ulaşmaktadır. Diyabet, hipertansiyon gibi eşlik eden komorbiditeler ve yaşlılarda daha fazla görülmektedir. İmmünosüpresif hasta grubu olan solid organ tranplantı olan hastalarda COVID-19'a bağlı gelişen viral pnömoni seyri hafif seyirden ağır seyre geniş yelpaze göstermektdir. Nakil hastalarında COVID-19 tarama ve tedavi yaklaşımları titizlikle değerlendirilmeli, geniş serilerle dokümente edilmelidir. Biz bu olgu sunumunda böbrek nakli olmuş mortaliteyle sonuçlanan COVID-19 olgusunu sunmayı amaçladık.

Anahtar Kelimeler: SARS-CoV-2 enfeksiyonu, COVID-19, İmmünosüpresyon, Böbrek nakli, Tedavi

\section{Introduction}

The first case of infection from the novel coronavirus, SARSCoV-2, named Coronavirus disease 2019 (COVID-19), was identified in Wuhan, China, in December 2019 and has become a pandemic; the COVID-19 infection is characterized by respiratory disease (1). COVID-19 has been reported to have a higher fatality rate and a more severe clinical course than other viral respiratory diseases, particularly in the elderly and those with comorbidities (2). Although patients can be asymptomatic or present either mild flu-like symptoms or severe upper respiratory tract infection, cases of severe viral pneumonia with respiratory failure have been encountered (3-5).

Severe clinical conditions have been reported in solid organ transplant (SOT) recipients owing to immunosuppression, and chronic immunosuppression has been shown to be a highly comorbid condition. Varying clinical results have been reported from China, Italy, and France for COVID-19 in SOT recipients on different immunosuppressive modalities (6-10). We aimed to present a fatal case of COVID-19 in kidney transplant recipient.

\section{Case Report}

A 47-year-old man who had undergone living-donor kidney transplantation at another hospital 8 years ago, presented to a health center with the complaints of fever, malaise, and cough, where COVID-19 was suspected and laboratory and thoracic computed tomography (CT) examinations were performed. The patient was referred to our clinic, which is a pandemic and organ transplantation center. The patient had fever (38.7

Correspondence: Bekir Voyvoda MD, University of Health Sciences Turkiye, Kocaeli Derince Training and Research Hospital, Organ Transplantation Center, Kocaeli, Turkiye Phone: +90 2623176200 E-mail: bvoyvoda@gmail.com ORCID-ID: orcid.org/0000-0002-0696-7381

Received: 03.06.2020

Accepted: 28.06 .2020

Cite this article as: Voyvoda B. COVID-19 with a Fatal Outcome in a Kidney Transplant Recipient: Case Report. J Urol. Surg 2020;7(4):328-330.

${ }^{\circ}$ Copyright 2020 by the Association of Urological Surgery / Journal of Urological Surgery published by Galenos Publishing House. 
$\left.{ }^{\circ} \mathrm{C}\right)$, malaise, and cough on presentation. Lung examination revealed bilateral diffuse coarse rales. His 02 saturation was $92 \%$, heart rate was $125 / \mathrm{min}$, and respiratory rate was $24 / \mathrm{min}$. The immunosuppression protocol of the patient was as follows: sirolimus (Rapamune) $2 \times 1 \mathrm{mg}$, mycophenolate mofetil (MMF) 2 $\times 500 \mathrm{mg}$, and steroid $1 \times 5 \mathrm{mg}$. In addition, he was administered amlodipine $10 \mathrm{mg}$ as an antihypertensive. His medical records showed that he primarily had renal amyloidosis because of familial Mediterranean fever. The patient was followed-up at our clinic 1 month prior, when he had a creatinine level of 2.67 $\mathrm{ng} / \mathrm{mL}$, and the graft biopsy performed approximately 1 year ago presented signs of chronic allograft nephropathy.

On hospitalization day 1, the patient's creatinine, C-reactive protein, and procalcitonin levels were $3.57 \mathrm{ng} / \mathrm{mL}, 70 \mathrm{mg} / \mathrm{L}$, and $0.14 \mathrm{ng} / \mathrm{mL}$, respectively, and his leukocyte and absolute lymphocyte counts were $5700 / \mu \mathrm{L}$ and $1000 / \mu \mathrm{L}$. His sirolimus level was $7.5 \mathrm{ng} / \mathrm{mL}$.

Thoracic CT showed involvement consistent with bilateral diffuse viral pneumonia (Figure 1).

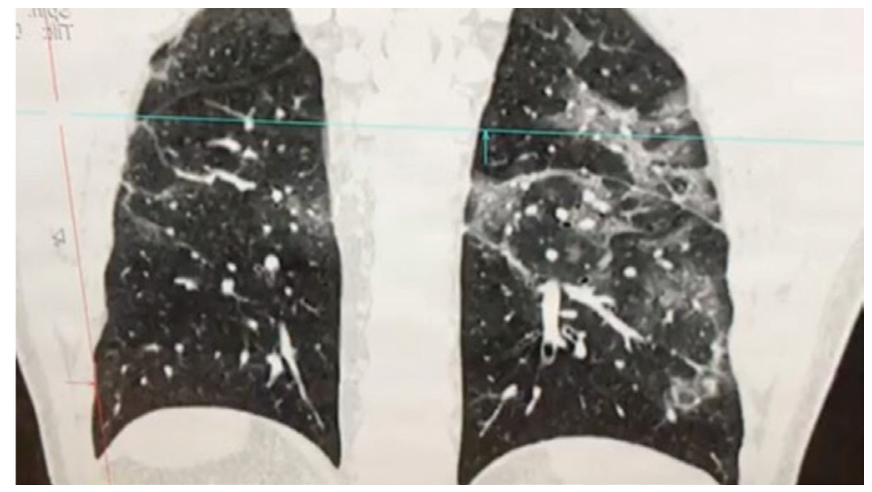

Figure 1. Thorax CT when symptoms appear. Bilateral lung involvement due to viral pneumonia

According to the COVID-19 Treatment Protocol of the Ministry of Health, the patient was initiated on oseltamivir $2 \times 75 \mathrm{mg}$, hydroxychloroquine $2 \times 200 \mathrm{mg}$, and azithromycin $1 \times 500 \mathrm{mg}$. On the third day of treatment, he developed severe respiratory distress, with decreased 02 saturation of $83 \%$. He was transferred to the intensive care unit, wherein he was intubated. We halved the MMF dose, and initiated favipiravir $2 \times 600 \mathrm{mg}$; however on hospitalization day 9 , the patient died. Table 1 summarizes the patient's laboratory examination results, clinical course, and treatment details.

The patient's PCR tests on hospitalization days 1 and 3 were negative for COVID-19. However, a PCR test conducted with the bronchoalveolar lavage sample collected from the endotracheal tube on hospitalization day 5 was positive for COVID-19.

\begin{tabular}{|c|c|}
\hline & Case \\
\hline Patient age, years & 47 \\
\hline $\begin{array}{l}\text { Time post-trasplant, } \\
\text { years }\end{array}$ & 8 \\
\hline Primary pathology & Renal amiloidosis \\
\hline \multicolumn{2}{|l|}{ Medical history } \\
\hline $\begin{array}{l}\text { İmmunsupressive } \\
\text { medications }\end{array}$ & $\begin{array}{l}\text { Sirolimus (target level 5-12 ng/mL), } \\
\text { mycophenolate mofetil, steroid }\end{array}$ \\
\hline Fever & Documented \\
\hline Symptoms & Fatigue, cough, and dyspnea \\
\hline $\begin{array}{l}\text { White blood cell count } \\
\text { (cells } / \mu \mathrm{L} \text { ) }\end{array}$ & $\begin{array}{l}\text { IIIness day } 1: 6700 \\
\text { IIIness day } 2: 12900 \\
\text { Illness day } 3: 2600\end{array}$ \\
\hline $\begin{array}{l}\text { Absolute lymphocyte } \\
\text { count (cells/ } \mu \mathrm{L} \text { ) }\end{array}$ & $\begin{array}{l}\text { Illness day } 1: 1000 \\
\text { IIIness day 5: } 400 \\
\text { IIIness day 9: } 700\end{array}$ \\
\hline D-dimer level (ng/mL) & $\begin{array}{l}\text { IIIness day } 1: 698 \\
\text { Illness day 5: } 2128 \\
\text { IIIness day 9: } 5228 \\
\end{array}$ \\
\hline Creatinine level (mg/dL) & $\begin{array}{l}\text { IIIness day } 1: 3.06 \\
\text { Illness day } 5: 3.2 \\
\text { Illness day } 9: 2.78\end{array}$ \\
\hline SARS-CoV-2 PCR results & $\begin{array}{l}\text { Illness day } 1: \text { Negative } \\
\text { Illness day } 3: \text { Negative } \\
\text { Illness day 5: Positive }\end{array}$ \\
\hline CT & Bilateral diffuse involvement \\
\hline Intubation & Yes \\
\hline Antiviral management & $\begin{array}{l}\text { Oseltamivir, hydroxychloroquine, } \\
\text { favipiravir }\end{array}$ \\
\hline Outcome & Exitus, day 9 \\
\hline
\end{tabular}

\section{Discussion}

The clinical course of our patient, who was an SOT recipient and contracted COVID-19, deteriorated rapidly, leading to mortality.

While COVID-19 pneumonia may not manifest typically a severe infection, it could lead to severe infection or even mortality in immunosuppressed patients, as in our case (11).

The study by Aslam and Mehra (12) that included 2 heart transplant recipients with COVID-19 reported the death of 1 patients because of severe pneumonia.

A study from China reported the different clinical courses of 2 heart transplant recipients with COVID-19, with 1 requiring prolonged hospitalization (39 days); however, both patients recovered (12).

Several case reports of SOT recipients contracting COVID-19 continue to be reported globally, with presentations ranging from mild to severe (13). 
Although viral infections are known to have a fatal course in transplant patients, age, sex, and comorbidities are important predictor of the course of COVID-19 in these patients. In addition to immunosuppression, hypertension and chronic allograft nephropathy were likely significant comorbidities in our patient; however, as is shown in the study by Liu et al. (14), lymphopenia and increased D-dimer levels from admission to death were important indicators of the poor clinical course.

\section{Conclusion}

In conclusion, we present a case of COVID-19 in a renal transplant recipient that resulted in mortality. However, several reports of mild infection in SOT recipients with COVID-19 exist. Hence, larger-scale studies are needed to conclusively determine the risk factors. The clinical of COVID-19 could be unpredictable in immunocompromised patients and hence, it should be tested for in all transplant patients.

\section{Ethics}

Peer-review: Externally peer-reviewed.

Conflict of Interest: No conflict of interest was declared by the authors.

Financial Disclosure: The authors declared that this study received no financial support.

\section{References}

1. Arpali E, Akyollu B, Yelken B, Tekin S, Turkmen A, Kocak B. Case report: A kidney transplant patient with mild COVID-19. Transpl Infect Dis 2020;22:e13296.

2. Lai CC, Shih TP, Ko WC, Tang HJ, Hsueh PR. Severe acute respiratory syndrome coronavirus 2 (SARS-CoV-2) and coronavirus disease-2019 (COVID- 19): the epidemic and the challenges. Int J Antimicrob Agents 2020;55:105924.

3. Huang $C$, Wang $Y$, Li X, Ren L, Zhao J, Hu Y, Zhang L, Fan G, Xu J, Gu X, Cheng Z, Yu T, Xia J, Wei Y, Wu W, Xie X, Yin W, Li H, Liu M, Xiao Y, Gao H,
Guo L, Xie J, Wang G, Jiang R, Gao Z, Jin Q, Wang J, Cao B. Clinical features of patients infected with 2019 novel coronavirus in Wuhan, China. Lancet 2020;395:497-506.

4. Wang D, Hu B, Hu C, Zhu F, Liu X, Zhang J, Wang B, Xiang H, Cheng Z, Xiong Y, Zhao Y, Li Y, Wang X, Peng Z. Clinical characteristics of 138 hospitalized patients with 2019 novel coronavirus-infected pneumonia in Wuhan, China. JAMA 2020;323:1061-1069.

5. Chen N, Zhou M, Dong X, Qu J, Gong F, Han Y, Qiu Y, Wang J, Liu Y, Wei Y, Xia J, Yu T, Zhang $X$, Zhang L. Epidemiological and clinical characteristics of 99 cases of 2019 novel coronavirus pneumonia in Wuhan, China: a descriptive study. Lancet 2020;395:507-513.

6. Zhu L, Xu X, Ma K, Yang J, Guan H, Chen S, Chen Z, Chen G. Successful recovery of COVID-19 pneumonia in a renal transplant recipient with longterm immunosuppression. Am J Transplant 2020:10.1111/ajt.15869.

7. Qin J, Wang $H$, Qin $X$, Zhang $P$, Zhu L, Cai J, Yuan Y, Li H. Perioperative presentation of COVID- 19 disease in a liver transplant recipient. Hepatology 2020

8. Seminari E, Colaneri M, Sambo M, Gallazzi I, Di Matteo A, Roda S, Bruno R, COVID19 IRCCS San Matteo Pavia Task Force. SARS Cov2 infection in a renal transplanted patients. A case report. Am J Transplant 2020;20:1882-1884.

9. Liu B, Wang $Y$, Zhao $Y$, Shi $H$, Zeng $F$, Chen Z. Successful treatment of severe COVID-19 pneumonia in a liver transplant recipient. Am J Transplant 2020;20:1891-1895.

10. Manuel O, Estabrook M, American Society of Transplantation Infectious Diseases Community of Practice. RNA respiratory viral infections in solid organ transplant recipients: Guidelines from the American Society of Transplantation Infectious Diseases Community of Practice. Clin Transplant 2019;33:e13511.

11. AlGhamdi M, Mushtaq $F$, Awn N, Shalhoub S. MERS CoV infection in two renal transplant recipients: case report. Am J Transplant 2015;15:1101-1104.

12. Aslam S, Mehra MR. COVID-19: yet another coronavirus challenge in transplantation. J Heart Lung Tranplant 2020;39:408-409.

13. Kates OS, Fisher CE, Stankiewicz-Karita HC, Shepherd AK, Church EC, Kapnadak SG, Lease ED, Riedo FX, Rakita RM, Limaye AP. Earliest cases of coronavirus disease 2019 (COVID-19) identified in solid organ transplant recipients in the United States. Am J Transplant 2020;20:1885-1890.

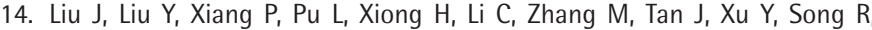
Song $M$, Wang L, Zhang W, Han B, Yang L, Wang $X$, Zhou G, Zhang T, Li B, Wang Y, Chen Z, Wang X. Neutrophil-to-Lymphocyte Ratio Predicts Severe IIIness Patients with 2019 Novel Coronavirus in the Early Stage. J Transl Med 2020;18. 